\title{
REVITALISASI BADAN WAKAF INDONESIA (BWI) ANALISIS KRITIS UNDANG-UNDANG NOMOR 41 TAHUN 2004 TENTANG WAKAF
}

\author{
Hidayatullah; Faris Ali Sidqi \\ Fakultas Hukum Universitas Islam Kalimantan MAB Banjarmasin \\ Jalan Adhyaksa Nomor 2 Kayutangi Banjarmasin \\ Email: hidayatullah250879@gmail.com; sidqifaris353@yahoo.com
}

\begin{abstract}
This study aims to illustrate how the existence and position of Badan Wakaf Indonesia according to Law Number 41 of 2004 concerning Waqf, will then be studied more deeply to find out how to revitalize the status, roles and responsibilities of Badan Wakaf Indonesia in managing waqf in Indonesia in the context of management endowments that are effective and effective. The establishment of Badan Wakaf Indonesia (BWI) is a consequence of the issuance of Law No. 41 of 2004 concerning Waqf so that Badan Wakaf Indonesia has a strong legal position in the structure of national law. However, in the legal construction of the authority, duties and responsibilities of Badan Wakaf Indonesia there are several shortcomings, namely related to the status, independence, structure, duties and funding of this institution, which has a very significant effect on the implementation, management and development of endowments in Indonesia. Therefore, one of the ways to revitalize the status, roles and responsibilities of the Indonesian Waqf Agency in waqf regulation is to improve the institutional status of Badan Wakaf Indonesia to become a Nonstructural Government Institution (LNS) so that it becomes clear in the constitutional system which is directly under the President and can budgeting for their own funds charged to the state budget, the institutional status can be equated with the National Zakat Amil Agency (BAZNAS).
\end{abstract}

Keywords: Revitalization, Badan Wakaf Indonesia, Endowments.

\begin{abstract}
Abstrak
Penelitian ini bertujuan untuk memberikan gambaran bagaimana eksistensi dan kedudukan Badan Wakaf Indonesia menurut Undang-Undang Nomor 41 Tahun 2004 tentang Wakaf, kemudian akan dikaji lebih dalam untuk menemukan bagaimana merevitalisasi status, peran dan tanggung jawab Badan Wakaf Indonesia dalam pengelolaan wakaf di Indonesia dalam konteks pengelolaan wakaf yang berdaya guna dan berhasil guna. Dibentuknya Badan Wakaf Indonesia (BWI) merupakan konsekuensi dari lahirnya Undang-Undang Nomor 41 Tahun 2004 tentang Wakaf sehingga Badan Wakaf Indonesia mempunyai kedudukan hukum yang kuat dalam struktur hukum nasional. Namun dalam konstruksi hukum tentang wewenang, tugas dan tanggungjawab Badan Wakaf Indonesia terdapat beberapa kekurangan, yaitu terkait dengan status, independensi, struktur, tugas dan pembiayaan lembaga ini, yang mana hal tersebut berpengaruh sangat signifikan terhadap pelaksanaan, pengelolaan dan pengembangan perwakafan di Indonesia. Oleh karena itu, salah satu langkah merevitalisasi status, peran dan tanggung jawab Badan Wakaf Indonesia dalam regulasi wakaf adalah dengan meningkatkan status kelembagaan Badan Wakaf Indonesia menjadi Lembaga Pemerintah Nonstruktural (LNS) sehingga menjadi jelas dalam sistem ketatanegaraan yang mana kedudukannya langsung berada di bawah Presiden dan dapat menganggarkan sendiri pembiayaannya yang
\end{abstract}


dibebankan kepada APBN, status kelembagaan tersebut dapat disamakan dengan Badan Amil Zakat Nasional (BAZNAS).

Kata kunci: Revitalisasi, Badan Wakaf Indonesia, Wakaf.

LATAR BELAKANG MASALAH

Lahirnya Undang-Undang Nomor 41 Tahun 2004 tentang Wakaf adalah berawal dari munculnya gagasan tentang wakaf tunai yang mengejutkan banyak kalangan, khususnya para ahli dan praktisi ekonomi Islam. Karena wakaf tunai berlawanan dengan persepsi umat Islam yang terbentuk bertahun-tahun lamanya, bahwa wakaf itu berbentuk benda-benda tak bergerak. Wakaf tunai bukan merupakan aset tetap yang berbentuk benda tak bergerak seperti tanah, melainkan aset lancar. Diakomodirnya wakaf tunai dalam konsep wakaf sebagai hasil interpretasi radikal yang mengubah definisi atau pengertian mengenai wakaf. Tafsiran baru ini dimungkinkan karena berkembangnya teori-teori ekonomi. ${ }^{1}$

Ide pengembangan organisasi wakaf pun digulirkan dalam rangka merespon wacana wakaf tunai tersebut, yang berarti akan memunculkan peluang luar biasa terhadap potensi wakaf secara umum. Lagkah pertama yang diusulkan adalah pembentukan Badan Wakaf Indonesia (BWI). Ide pembentukan Badan Wakaf Indonesia (BWI) diusulkan oleh Menteri Agama RI secara langsung kepada Presiden Republik Indonesia, Megawati Soekarno

\footnotetext{
1 Abdul Halim, Hukum Perwakafan di
} Indonesia, Ciputat Press, Tangerang, 2005, hlm. 6.
Putri melalui surat Nomor: MA/320/2002 tertanggal 5 September 2002. Usul pembentukan Badan Wakaf Indonesia (BWI) dari Menteri Agama kepada Presiden berbuah usulan dari Sekretariat Negara agar Departemen Agama RI mengirim surat izin prakarsa untuk menyusun draf Rancangan Undang-Undang (RUU) tentang wakaf. Langkah yang kemudian disiapkan oleh Direktorat Zakat dan Wakaf cq. Menteri Agama adalah mengirim surat Bernomor: MA/451/2002 tertanggal 27 Desember 2002 kepada Menteri Kehakiman dan Hak Asasi Manusia perihal izin prakarsa RUU perwakafan. $^{2}$

\section{Lahirnya Undang-Undang Nomor}

41 Tahun 2004 tentang Wakaf juga membawa konsekuensi bagi sistem pengelolaan wakaf di Indonesia agar lebih professional dan independen. Untuk itu diperlukan suu lembaga baru yang memiliki kapasitas dan kapabilitas dalam memberdayakan asset wakaf di Indonesia agar lebih produktif. Pentingnya pembentukan sebuah lembaga wakaf nasional yang bersifat independen diperlukan dalam rangka untuk membina Nazhir (pengurus harta wakaf)

2 Direktorat Pemberdayaan Wakaf, Proses Lahirnya UU Nomor 41 Tahun 2004 tentang Wakaf, Direktorat Jenderal Bimbingan Masyarakat Islam, Jakarta, 2006, hlm. 20. 
dalam mengelola dan mengembangkan harta benda wakaf baik secara nasional maupun internasional.

Badan Wakaf Indonesia (BWI) pun lahir sebagai jawaban bagi pengembangan pengelolaan perwakafan Indonesia dengan lebih profesional dan modern sehingga menghasilkan manfaat wakaf yang dapat mensejahterakan umat. Sehingga kelak Badan Wakaf Indonesia akan menduduki peran kunci, selain berfungsi sebagai Nazhir, BWI juga akan sebagai Pembina Nazhir sehingga harta benda wakaf dapat dikelola dan dikembangkan secara produktif. ${ }^{3}$

Oleh karena itu Badan Wakaf Indonesia (BWI) ke depan tidak hanya berfungsi sebagai lembaga yang mengelola wakaf secara independen dan mandiri agar dana yang dikelola lebih produktif, akan tetapi fungsi penyadaran dan sosialisasi terhadap masalah wakaf, baik fungsi dan manfaatnya kepada masyarakat harus juga dimainkan perannya oleh Badan Wakaf Indonesia itu sendiri. Selama ini memang efektifitas untuk memberdayakan wakaf dan juga menarik dana wakaf dari masyarakat untuk dikelola oleh lembaga wakaf belum maksimal. Hal ini karena

3 Sigit Indra Prianto, Peran BWI Dalam Mengembangkan Wakaf Indonesia, http://sigitsoebroto.blogspot.com/2009/06/peranbwi-dalam-mengembangkan-wakaf.html, diakses pada 23 September 2018 . realisasi pencapaian di lapangan dengan potensi wakaf dimasyarakat sendiri belum berbanding lurus dan mencapai titik yang ideal

Mengingat begitu pentingnya peran Badan Wakaf Indonesia (BWI) dalam pengelolaan wakaf, maka diperlukan suatu kajian yang bertujuan untuk meningkatkan eksistensi Badan Wakaf Indonesia (BWI) dalam pengelolaan wakaf guna terwujudnya pengelolaan wakaf yang profesional, tepat, efektif dan efisien. Oleh karena itu, langkah-langkah revitalisasi tugas, fungsi dan wewenang Badan Wakaf Indonesia (BWI) dalam regulasi wakaf merupakan suatu keniscayaan yang mau tidak mau harus diperjelas dan ditegaskan kembali ataupun dimodifikasi oleh pihak pembentuk undang-undang. Berdasarkan hal tersebut, maka penulis berinisiatif untuk menelaah dan meneliti eksistensi Badan Wakaf Indonesia dalam bentuk penelitian yang berjudul: "REVITALISASI BADAN WAKAF INDONESIA (BWI) Analisis Kritis Undang-Undang Nomor 41 Tahun 2004 tentang Wakaf'.

\section{RUMUSAN MASALAH}

Berdasarkan uraian di atas, untuk memfokuskan aspek penelitian ini, maka diformulasikan rumusan masalah pada 
penelitian ini sebagai berikut:

1. Bagaimana kedudukan Badan Wakaf Indonesia dalam UndangUndang Nomor 41 Tahun 2004 tentang Wakaf?

2. Bagaimana merevitalisasi status, peran dan tanggung jawab Badan Wakaf Indonesia dalam pengelolaan wakaf di Indonesia?

\section{METODE PENELITIAN}

\section{Jenis dan Pendekatan Penelitian}

Penelitian ini dilakukan dengan jenis penelitian hukum normatif berupa penelitian kepustakaan yang menggunakan 3 (tiga) bahan hukum yaitu bahan hukum primer, bahan hukum sekunder dan bahan hukum tersier. Penelitian hukum ini menitikberatkan pada studi kepustakaan yang berarti akan lebih banyak menelaah dan mengkaji aturan-aturan hukum yang ada dan berlaku. Dalam penelitian ini memerlukan bahan-bahan hukum hukum karena akan berfungsi untuk melengkapi dan menunjang bahan hukum dalam penelitian kepustakaan (library research).

\section{Sumber Data}

Sumber data dari penelitian ini terdiri dari Bahan Hukum Primer yaitu: Undang-undang Nomor 41 Tahun 2004 Tentang Wakaf; Peraturan Pemerintah Nomor 42 Tahun 2006 Tentang Pelaksanaan Undang-undang Nomor 41 Tahun 2004 Tentang Wakaf; dan Peraturan Badan Wakaf Indonesia Nomor 1 Tahun
2007 tentang Organisasi dan Tata Kerja Badan Wakaf Indonesia. Bahan Hukum Sekunder yaitu berupa: Buku-buku Hukum; Jurnal-jurnal Hukum; Karya Tulis Hukum atau Pandangan Ahli Hukum yang termuat dalam media masa, Internet. Dan Bahan Hukum Tertier, yakni bahan yang memberikan petunjuk maupun penjelasan terhadap hukum primer dan sekunder; contohnya adalah kamus, ensiklopedia, indeks kumulatif dan seterusnya.

\section{PEMBAHASAN}

Kedudukan Badan Wakaf Indonesia dalam Undang-Undang Nomor 41 Tahun 2004 tentang Wakaf

BWI merupakan lembaga independen dalam melaksanakan tugasnya, ${ }^{4}$ dalam rangka memajukan dan mengembangkan perwakafan nasional maupun internasional. Kelahiran Badan Wakaf Indonesia (BWI) merupakan perwujudan amanat yang digariskan dalam UU Wakaf. Kehadiran BWI, sebagaimana dijelaskan dalam pasal 47, adalah untuk memajukan dan mengembangkan perwakafan di Indonesia. Untuk kali pertama, Keanggotaan BWI diangkat oleh Presiden Republik Indonesia, sesuai dengan Keputusan Presiden (Kepres) No. 75 tahun 2007, yang ditetapkan di Jakarta, 13 Juli 2007. Berdasarkan Pasal 1 Undang-Undang Nomor 41 Tahun 2004 tentang Wakaf dijelaskan bahwa: "Badan Wakaf Indonesia

4 Undang-Undang Nomor 41 Tahun 2004 tentang Wakaf Pasal 47 (2) 
adalah lembaga independen untuk mengembangkan perwakafan di Indonesia", maka dapat dipastikan bahwa BWI merupakan lembaga yang bersifat independen untuk menjalankan permasalahan perwakafan di Indonesia, dan dalam melaksanakan tugasnya tersebut bersifat bebas dari pengaruh kekuasaan manapun serta bertanggung jawab kepada masyarakat.

Mengingat BWI lahir berdasarkan amanat Undang-Undang, maka sebagaimana kedudukan Undang-Undang, yaitu amanat dari oleh Undang-Undang Nomor 41 Tahun 2004 tentang Wakaf, dengan demikian maka BWI mempunyai kedudukan hukum yang kuat dalam struktur hukum nasional. Seiring dengan ketentuan status tersebut, tentunya Undang-Undang juga memberikan tugas dan wewenang bagi BWI secara kelembagaan. Tugas dan wewenang tersebut, salah satunya diwujudkan dalam Pasal 49 Ayat 1 Undang-Undang Nomor 41 Tahun 2004 tentang Wakaf, bahwa BWI mempunyai tugas dan wewenang sebagai berikut:

1. Melakukan pembinaan terhadap Nazhir dalam mengelola dan mengembangkan harta benda wakaf;

2. Melakukan pengelolaan dan pengembangan harta benda wakaf berskala nasional dan internasional;
3. Memberikan persetujuan dan atau izin atas perubahan peruntukan dan status harta benda wakaf;

4. Memberhentikan dan mengganti nazhir;

5. Memberikan persetujuan atas penukaran harta benda wakaf; dan

6. Memberikan saran dan pertimbangan kepada Pemerintah dalam penyusunan kebijakan di bidang perwakafan. ${ }^{5}$

Kemudian, melalui Peraturan BWI Nomor 1 Tahun 2007 tentang Organisasi dan Tata Kerja Badan Wakaf Indonesia, BWI menjabarkan tugas dan wewenangnya sebagai berikut:

1. Melakukan pembinaan terhadap nazhir dalam mengelola dan mengembangkan harta benda wakaf;

2. Membuat pedoman pengelolaan dan pengembangan harta benda wakaf;

3. Melakukan pengelolaan dan pengembangan harta benda wakaf berskala nasional dan internasional serta harta benda wakaf terlantar;

4. Memberikan pertimbangan, persetujuan, dan/atau izin atas perubahan peruntukan dan status harta benda wakaf;

${ }^{5}$ Undang-Undang Nomor 41 Tahun 2004 Tentang Wakaf Pasal 49. 
5. Memberikan pertimbangan dan/ atau persetujuan atas penukaran harta benda wakaf;

6. Memberikan saran dan pertimbangan kepada Pemerintah dalam penyusunan kebijakan di bidang perwakafan;

7. Menerima, melakukan penilaian, menerbitkan tanda bukti pendaftaran nazhir, dan mengangkat kembali nazhir yang telah habis masa baktinya;

8. Memberhentikan dan mengganti nazhir bila dipandang perlu;

9. Memberikan saran dan pertimbangan kepada Menteri Agama dalam menunjuk Lembaga Keuangan Syariah Penerima Wakaf Uang (LKS-PWU); dan

10. Menerima pendaftaran Akta Ikrar Wakaf (AIW) benda bergerak selain uang dari Pejabat Pembuat Akta Ikrar Wakaf (PPAIW). ${ }^{6}$

Dalam melaksanakan tugas dan wewenangnya BWI bekerja sama dengan Kementerian Agama (c.q. Direktorat Pemberdayaan Wakaf), Majelis Ulama Indonesia, Badan Pertanahan Nasional, Bank Indonesia, Badan Perencanaan Pembangunan Nasional, Islamic Development Bank, dan berbagai lembaga lain. Tidak tertutup kemungkinan BWI juga bekerja sama dengan pengusaha/ investor

${ }^{6}$ Lihat Peraturan Badan Wakaf Indonesia Nomor 1 Tahun 2007 tentang Organisasi dan Tata Kerja Badan Wakaf Indonesia. dalam rangka mengembangkan aset wakaf agar menjadi lebih produktif.

Bersama adanya tugas dan wewenang yang diberikan oleh UndangUndang Nomor 41 Tahun 2004 tentang Wakaf, sebagai kewajibannya maka BWI diberikan ketentuan pertanggungjawabannya sebagaimana yang diatur dalam pasal 61 yang berbunyi:

(1) Pertanggungjawaban pelaksanaan tugas Badan Wakaf Indonesia dilakukan melalui laporan tahunan yang diaudit oleh lembaga audit independen dan disampaikan kepada Menteri.

(2) Laporan tahunan sebagaimana dimaksud pada ayat diumumkan kepada masyarakat.

Dengan demikian, setelah menjalankan tugas dan wewenangnya, BWI diperintahkan oleh Undang-Undang untuk bertanggungjawab kepada Menteri dan mengumumkan hasil laporan tahunannya kepada masyarakat. Oleh karena itu, menurut hemat penulis bahwa dengan adanya ketentuan tentang tugas, wewenang dan kewajiban tersebut di atas, maka BWI dari sudut pandang kelembagaan negara telah memiliki aturan yang lengkap sebagaimana lembaga negara pada umumnya.

Ironisnya, di balik status hukum lembaga Badan Wakaf Indonesia yang kuat tersebut, dalam konstruksi hukum wewenang, tugas dan tanggungjawabnya terdapat beberapa kekurangan yang dimiliki oleh Undang-Undang Nomor 41 Tahun 
2004 tentang Wakaf, yaitu terkait dengan, status, independensi, struktur, tugas dan pembiayaan Badan Wakaf Indonesia (BWI), yang mana hal tersebut berpengaruh sangat signifikan terhadap pelaksanaan, pengelolaan dan pengembangan perwakafan di Indonesia.

Dari segi susunan tata Negara Indonesia, status BWI ini tidak jelas. Hal tersebut dapat sebagaimana yang diatur pada 2 (dua) pasal, yaitu dalam pasal 1 dan pasal 47 ayat (2) sebagai berikut:

(1) Pasal 1 angka 7 yang berbunyi: "Badan Wakaf Indonesia adalah lembaga independen untuk mengembangkan perwakafan di Indonesia"?

(2) Pasal 47 ayat (2) yang berbunyi: "Badan Wakaf Indonesia merupakan lembaga independen dalam melaksanakan tugasnya".

Berdasarkan kedua pasal tersebut maka sangat jelas bahwa status BWI ini mencurigakan, karena di satu sisi dalam hal perwakafan di Indonesia BWI yang bertanggungjawab namun dari sisi regulasi tidak jelas, BWI tidak termasuk dalam lembaga Non Struktural apalagi dalam Lembaga Struktural, apakah sifatnya permanen atau hanya adhock, juga tidak dijelaskan dalam Undang-Undang Wakaf ini ataupun dalam Peraturan Pemerintah Nomor 42 Tahun 2006 tentang Pelaksanaan

7 Lihat Undang-Undang Nomor 41 Tahun 2004 tentang Wakaf, Pasal 1.
Undang-Undang Nomor 41 Tahun 2004 tentang Wakaf.

Dengan ketidakjelasan status yang disandang oleh BWI, maka hal tersebut berdampak terhadap independensinya. Jelas BWI adalah lembaga independen sebagaimana Pasal 1 angka 7 dan pasal 47 ayat (2) di atas. Namun independensi tersebut dipertanyakan, karena dari beberapa pasal, ${ }^{8}$ sebagaimana dimuat dalam Undang-Undang Wakaf ini, dalam konteks pelaksanaan pengelolaan dan pengembangan wakaf selalu dihantui oleh Kementerian Agama. Menteri Agama tidak hanya bergelut dalam pengawasan terhadap BWI tetapi juga ikut campur dalam pelaksanaan perwakafan yang seharusnya dilakukan oleeh BWI secara independen.

Oleh karena itu, dalam konteks ini tidaklah salah jika diambil hipotesis bahwa sepertinya Pemerintah masih setengah hati dan/atau tidak serius menobatkan BWI sebagai lembaga wakaf yang Independen yang khusus melaksanakan pengelolaan dan pengembangan wakaf di Indonesia.

Ketidakseriusan Pemerintah tersebut pada akhirnya dibuktikan lagi dengan keadaan struktur BWI yang tidak diatur dalam Undang-Undang Wakaf secara lugas

${ }^{8}$ Lihat Undang-Undang Nomor 41 Tahun 2004 tentang Wakaf, Pasal 14 ayat (1) beserta Penjelasannya, pasal 13, Pasal 14, Pasal 37, Pasal 38 dan Pasal 41. 
dan tegas. BWI hanya berkedudukan di Jakarta sebagai Ibukota Negara Kesatuan Republik Indonesia, tetapi melalui struktur BWI di Provinsi dan Kabupaten/Kota tidak diatur, layaknya Lembaga Zakat yang mana zakat juga merupakan instrument religious/keagamaan yang dijadikan hukum positif. Seyogyanya keberadaan BWI tingkat Provinsi dan Kabupaten/Kota juga diakomodasi dalam Undang-Undang Wakaf ini.

Mengenai kedudukan dan struktur lembaga BWI ini dapat kita lihat pada pasal 48, yang berbunyi sebagai berikut:

Badan Wakaf Indonesia berkedudukan di ibukota Negara Kesatuan Republik Indonesia dan dapat membentuk perwakilan di Provinsi dan/atau Kabupaten/Kota sesuai dengan kebutuhan.

Dari pasal tersebut di atas, maka secara eksplisit hanya kedudukan BWI yang diatur oleh Undang-Undang, dalam untuk tingkat Provinsi dan Kabupaten/Kota tidak diatur secara tegas, ketidaktegasan tersebut dapat kita lihat dari kalimat “...dan dapat membentuk perwakilan di Provinsi dan/atau Kabupaten/Kota sesuai dengan kebutuhan." Kata "dapat" dan "dan/atau" adalah bukti ketidaktegasan bahkan ketidakseriusan para pembuat UndangUndang Wakaf tersebut dalam mewujudkan perwakafan yang membawa kesejahteraan umum.

$$
\text { Selanjutnya, dampak }
$$

ketidakseriusan Pemerintah tersebut dalam mengelola dan mengembangkan Wakaf dan dalam membentuk lembaga wakaf yaitu BWI dapat kita lihat pada Pasal 59 UndangUndang Nomor 41 Tahun 2004 tentang Wakaf yang berbunyi:

"Dalam rangka pelaksanaan tugas Badan Wakaf Indonesia, Pemerintah wajib membantu biaya operasional."

Dari pasal tersebut, maka jelas bahwa BWI tidak dibiayai oleh APBN tetapi oleh bantuan Pemerintah. Seharusnya untuk mewujudkan pengelolaan dan pengembangan wakaf yang mempunyai potensi dan manfaat ekonomis yang sangat besar dalam rangka memajukan kesejaheraan umum, maka lembaga wakaf harus juga diprioritaskan oleh Pemerintah dalam hal pembiayaannya, yaitu membebankan biaya operasional BWI ke dalam APBN.

Selanjutnya, ketidakpantasan aturan yang menjadi kelemahan dari UndangUndang Wakaf ini adalah mengenai tugas dan wewenang BWI yang diatur dalam Pasal 49, sebagai berikut:

(1) Badan Wakaf Indonesia mempunyai tugas dan wewenang:

a. melakukan pembinaan terhadap Nazhir dalam mengelola dan mengembangkan harta benda wakaf;

b. melakukan pengelolaan dan pengembangan harta benda wakaf berskala nasional dan internasional;

c. memberikan persetujuan dan/atau izin atas perubahan peruntukan dan status harta benda wakaf; 
d. memberhentikan dan mengganti Nazhir;

e. memberikan persetujuan atas penukaran harta benda wakaf;

f. memberikan saran dan pertimbangan kepada Pemerintah dalam penyusunan kebijakan di bidang perwakafan.

(2) Dalam melaksanakan tugas sebagaimana dimaksud pada ayat (1) Badan Wakaf Indonesia dapat bekerjasama dengan instansi Pemerintah baik Pusat maupun Daerah, organisasi masyarakat, para ahli, badan internasional, dan pihak lain yang dipandang perlu.

Terkait pasal 49 ayat (1) huruf d di atas tentang pemberhentian dan penggantian Nazhir haruslah ditiadakan karena bukan BWI yang mengangkat Nazhir, BWI hanya mendata atau bahkan hanya memiliki data dari Nazhir yang mendaftarkan diri ke BWI dan ke Kementerian Agama melalui KUA.

Dengan status Badan Wakaf Indonesia yang independen tetapi secara tekstual (regulasi) dan kontekstual (aplikasi), tidak regular ini mengakibatkan birokrasi pelaksanaannya berbelit-belit. Hal ini dapat dilihat dari beberapa pasal, di antanya 4 (empat) Pasal sebagai berikut:

1. Pasal 13, yang berbunyi: "Dalam melaksanakan tugas sebagaimana dimaksud dalam Pasal 11, Nazhir memperoleh pembinaan dari Menteri dan Badan Wakaf Indonesia".

2. Pasal 14, yang ayat-ayatnya berbunyi:

(1) Dalam rangka pembinaan sebagaimana dimaksud dalam Pasal 13, Nazhir harus terdaftar pada Menteri dan Badan Wakaf Indonesia.

(2) Ketentuan lebih lanjut mengenai Nazhir sebagaimana dimaksud dalam Pasal 9 Pasal 10, Pasal 11, Pasal 12, dan Pasal 13, diatur dengan Peraturan Pemerintah.

Dari uraian di atas, penulis menilai bahwa dengan adanya muatan materi Undang-Undang Wakaf yang mengharuskan BWI melaksanakan tugas dan wewenang yang selalu dibarengi oleh Kementerian Agama, maka dalam aplikasinya sangat membuat birokrasi menjadi panjang, dan hal ini pada akhirnya membuat masyarakat dapat mengurungkan niatnya untuk mewakafkan harta benda untuk kepentingan. Seharusnya jika pemerintah memang serius untuk mengelola dan mengembangkan perwakafan di Indonesia birokrasi wajib dipangkas guna memudahkan masyarakat atau Wakif dalam mendaftarkan harta benda wakaf.

Berkenaan dengan birokrasi ini pula, ada sebuah pertanyaan besar yang dapat Penulis sampaikan, yaitu: $A d a$ permalahan apa sehingga Kementerian Agama tidak dapat membiarkan BWI melaksanakan tugas kewakafan secara mandiri dan benar-benar independen?. Pertanyaan seperti ini berdasarkan dari 
beberapa pasal yang selalu menggandengkan Kementeraian Agama (Menteri) dengan BWI, padahal dalam ketentuan umum Pasal 1 dan Pasal 47, BWI adalah lembaga Independen.

\section{Revitalisasi Status, Peran dan Tanggung} Jawab Badan Wakaf Indonesia dalam

\section{Pengelolaan Wakaf di Indonesia}

Dalam hal strukturisasi lembaga Wakaf maka materi muatan selanjutnya adalah mengenai pembentukan sebuah lembaga wakaf nasional sebagaimana Pasal 47 sampai dengan Pasal 50 yang disebut dengan nama Badan Wakaf Indonesia (BWI).

Badan Wakaf ini bersifat independen bertujuan untuk membina nazhir dalam mengelola dan mengembangkan harta benda wakaf baik secara nasional maupun internasional. Sehingga BWI seharusnya menduduki peran kunci, selain berfungsi sebagai nazhir juga berfungsi sebagai pembina nazhir sehingga harta benda wakaf dapat dikelola dan dikembangkan secara produktif.

BWI merupakan lembaga independen dalam melaksanakan tugasnya, dalam rangka memajukan dan mengembangkan perwakafan nasional maupun internasional. Kelahiran Badan Wakaf Indonesia (BWI) merupakan perwujudan amanat yang digariskan dalam UU Wakaf. Kehadiran BWI, sebagaimana dijelaskan dalam pasal 47, adalah untuk memajukan dan mengembangkan perwakafan di Indonesia. Untuk kali pertama, Keanggotaan BWI diangkat oleh Presiden Republik Indonesia, sesuai dengan Keputusan Presiden (Kepres) No. 75 tahun 2007, yang ditetapkan di Jakarta, 13 Juli 2007. Jadi, BWI adalah lembaga independen untuk mengembangkan perwakafan di Indonesia yang dalam melaksanakan tugasnya bersifat bebas dari pengaruh kekuasaan manapun serta bertanggung jawab kepada masyarakat.

Sebagaimana Pasal 49 ayat 1 Undang-Undang Nomor 41 Tahun 2004 tentang Wakaf disebutkan bahwa BWI mempunyai tugas dan wewenang sebagai berikut:

(1) Melakukan pembinaan terhadap nazhir dalam mengelola dan mengembangkan harta benda wakaf;

(2) Melakukan pengelolaan dan pengembangan harta benda wakaf berskala nasional dan internasional;

(3) Memberikan persetujuan dan atau izin atas perubahan peruntukan dan status harta benda wakaf;

(4) Memberhentikan dan mengganti nazhir;

(5) Memberikan persetujuan atas penukaran harta benda wakaf; dan

(6) Memberikan saran dan pertimbangan kepada Pemerintah dalam penyusunan kebijakan di bidang perwakafan. 
Enam tugas Badan Wakaf Indonesia yang ditetapkan dalam Undang-Undang Nomor 41 Tahun 2004 tentang Wakaf sebagaimana disebutkan di atas, dapat dibedakan menjadi 3 (tiga):

(1) Tugas Badan Wakaf Indonesia yang berkaitan dengan nazhir, yaitu pengangkatan, pemberhentian, dan pembinaan nazhir;

(2) Tugas Badan Wakaf Indonesia yang berkaitan dengan obyek wakaf, yaitu pengelolaan dan pengembangan obyek wakaf yang berskala nasional atau internasional, serta pemberian persetujuan atas penukaran harta benda wakaf;

(3) Tugas Badan Wakaf Indonesia yang berkaitan dengan pemerintah, yaitu memberi saran dan pertimbangan kepada pemerintah dalam penyusunan kebijakan di bidang perwakafan. ${ }^{9}$

Dalam melaksanakan tugasnya, Badan Wakaf Indonesia bekerja sama dengan isntansi pemerintah pusat dan daerah, organisasi masyarakat, para ahli, badan internasional, dan pihak lain yang dipandang perlu. ${ }^{10}$ Di samping itu, Badan

${ }^{9}$ Jaih Mubarok, Wakaf Produktif, Simbiosa Rekatama Media, Bandung, 2008, hlm. 166.

${ }^{10}$ Lihat Undang-Undang Nomor 41 Tahun 2004 tentang Wakaf, Pasal 49, ayat (2).
Wakaf Indonesia juga harus memerhatikan saran dan pertimbangan Menteri Agama dan Majelis Ulama Indonesia dalam melaksanakan tugasnya. ${ }^{11}$

Pada ayat 2 dalam pasal yang sama dijelaskan bahwa dalam melaksanakan tugasnya BWI dapat bekerjasama dengan instansi Pemerintah baik Pusat maupun Daerah, organisasi masyarakat, para ahli, badan internasional, dan pihak lain yang dianggap perlu. Dalam melaksanakan tugas-tugas itu BWI memperhatikan saran dan pertimbangan Menteri dan Majelis Ulama Indonesia, seperti tercermin dalam pasal 50. Terkait dengan tugas dalam membina nazhir, BWI melakukan beberapa langkah strategis, sebagaimana disebutkan dalam pasal 53 PP No.42 Tahun 2006, meliputi:

(1) Penyiapan sarana dan prasarana penunjang operasional Nazhir wakaf baik perseorangan, organisasi dan badan hukum;

(2) Penyusunan regulasi, pemberian motivasi, pemberian fasilitas, pengkoordinasian, pemberdayaan dan pengembangan terhadap harta benda wakaf;

(3) Penyediaan fasilitas proses sertifikasi Wakaf;

${ }^{11}$ Lihat Undang-Undang Nomor 41 Tahun 2004 tentang Wakaf, Pasal 50. 
(4) Penyiapan dan pengadaan blankoblanko AIW, baik wakaf benda tidak bergerak dan/atau benda bergerak;

(5) Penyiapan penyuluh penerangan di daerah untuk melakukan pembinaan dan pengembangan wakaf kepada Nazhir sesuai dengan lingkupnya;

(6) Pemberian fasilitas masuknya danadana wakaf dari dalam dan luar negeri dalam pengembangan dan pemberdayaan wakaf.

Jadi dalam konteks pelaksanaannya, BWI dalam pengembangan wakaf uang mempunyai banyak fungsi, yaitu BWI sebagai Nazhir atau di sini BWI sebagai Motivator, Fasilitator, Regulator sekaligus Operator. Fungsi BWI salah satunya sebagai Nazhir, tugas dan kewenangan sudah dijelaskan secara rinci di atas termasuk sebagai Nazhir, yaitu melakukan pengelolaan dan pengembangan harta benda wakaf berskala nasional dan internasional.

BWI sebagai Motivator mempunyai tugas sebagai lembaga yang memberi ransangan atau stimulus, khususnya terhadap para Nazhir baik perorangan maupun organisasi untuk memaksimalkan fungsi pengelolaan benda-benda wakaf secara profesional, dan memberi rangsangan untuk meningkatkan kesadaran dan kemauan pada masyarakat luas untuk berwakaf.
BWI sebagai fasilitator, BWI memberikan fasilitas-fasilitas yang memungkinkan terhadap para Nazhir, wakif, calon wakif, lembaga atau pihak lain yang terkait dengan perwakafan secara fisik atau non fisik dalam mengomtimalkan peran pengelolaan, pengembangan, pelaporan dan pengawasan harta benda wakaf di Indonesia. Dalam hal ini BWI memberi fasilitas dengan mengadakan pelatihan Nazhir, sertifikasi Nazhir dan membuat rekening BWI pada LKS-PWU sebagai tempat berwakaf uang.

Regulator adalah salah satu fungsi BWI di mana BWI menjadi pihak yang memantau seluruh kebijakan dan peraturan perundang-undangan perwakafan, dan peraturan-peraturan terkait perwakafan yang dianggap relevan atau tidak serta mengusulkan perubahan kebijakan, bahkan BWI diberi kewenangan oleh UU Wakaf untuk membuat peraturan sendiri dengan acuannya undang-undang dan mengambil kebijakan yang terkait dengan perwakafan dengan memperhatikan pihak-pihak yang terkait.

Tugas-tugas di atas tentu tak mudah diwujudkan. Jadi, dibutuhkan profesionalisme, perencanaan yang matang, keseriusan, kerjasama, dan tentu saja amanah dalam mengemban tanggung jawab. Untuk itu, BWI merancang visi dan misi, serta strategi implementasi. Visi BWI adalah "Terwujudnya lembaga independen yang dipercaya masyarakat, mempunyai 
kemampuan dan integritas untuk mengembangkan perwakafan nasional dan internasional". Sedangkan misinya yaitu "Menjadikan Badan Wakaf Indonesia sebagai lembaga profesional yang mampu mewujudkan potensi dan manfaat ekonomi harta benda wakaf untuk kepentingan ibadah dan pemberdayaan masyarakat".

Adapun strategi untuk merealisasikan Visi dan Misi Badan Wakaf Indonesia adalah sebagai berikut:

(1) Meningkatkan kompetensi dan jaringan Badan wakaf Indonesia, baik nasional maupun internasional;

(2) Membuat peraturan dan kebijakan di bidang perwakafan.;

(3) Meningkatkan kesadaran dan kemauan masyarakat untuk berwakaf;

(4) Meningkatkan profesionalitas dan keamanahan nazhir dalam pengelolaan dan pengembangan harta wakaf;

(5) Mengkoordinasi dan membina seluruh nazhir wakaf;

(6) Menertibkan pengadministrasian harta benda wakaf;

(7) Mengawasi dan melindungi harta benda wakaf;

(8) Menghimpun, mengelola dan mengembangkan harta benda wakaf yang berskala nasional dan internasional.

Dari strategi di atas dapat dijabarkan bahwa strategi BWI dalam pemberdayaan wakaf ini berjalan sebagai pelaksanaan tugas BWI yang tercantum dalam UU wakaf, BWI mempunyai strategi meningkatkan kompetensi dan jaringan BWI baik nasional maupun internasional.

Terdapat persoalan yang sangat penting dalam hal ini adalah tentang kelembagaan Badan Wakaf Indonesia (BWI). Meskipun tingkat derajat religisitas yang berbeda, namun melihat urgensinya seharusnya BWI dapat disamakan status dan kedudukannya dengan BAZNAS. BWI merupakan lembaga yang bersifat independen dalam mengelola perwakafan di seluruh Indonesia, akan tetapi aturan-aturan yang dirumuskan, dibentuk dan dimuat dalam Undang-Undang Nomor 41 Tahun 2004 tentang Wakaf sepertinya tidak menghendaki independensi tersebut. BWI senantiasa dibayang-bayangi oleh Menteri Agama dalam mengelola dan mengembangkan wakaf. Hal ini jelas bahwa tidak akan ada nilai independensi yang dimiliki oleh BWI jika Menteri Agama selalu ikut campur.

Padahal jika Pemerintah serius ingin memberdayakan potensi wakaf di Indonesia, maka ada beberapa Negara Islam 
yang harus diadopsi sistem dan mekanisme pengelolaan wakafnya, baik itu dari infrastruktur maupun suprastruktur pengelolaan dan pengembangan aset wakaf, sebagai contoh adalah Arab Saudi, Turki dan Mesir. Ketiga Negara tersebut berhasil dalam pengelolaan wakaf, dikarenakan adanya keseriusan terhadap hal tersebut sehingga permasalahan wakaf menjadi urgen dalam ketiga Negara tersebut. Dengan demikian, permasalahan wakaf diatur dan diurus oleh kementerian, badan atau satuan perangkat Negara yang memang khusus untuk mengelola, memberdayakan dan mengembangkan wakaf.

Lain halnya dengan keberadaan Badan Wakaf Indonesia, yang merupakan lembaga Independen akan tetapi masih diintervensi oleh Pemerintah. Campur tangan Pemerintah menjadikan BWI tidak mandiri dalam pengelolaan dan pengembangan perwakafan di Indonesia, BWI terkekang dengan regulasi yang masih mempenjarakannya dalam bingkai koordinasi dengan Kementerian Agama. Seyogyanya, Kementerian Agama berbesar hati untuk menyerahkan pengelolaan wakaf kepada BWI secara penuh, dan bertindak hanya sebagai badan pengawas saja, tidak masuk ke ranah sistem dan mekanisme perwakafan.

Status BWI yang tidak jelas ini, membuat hal-hal terkait yang sifatnya urgen dalam pelaksanaan perwakafan pun menjadi tidak jelas pula. Sebagai salah satu contohnya

adalah ketidakjelasan pembiayaan yang diperuntukkan terhadap BWI dalam melaksanakan tugas, fungsi dan kewajibannya. Dengan rezim hukum yang bersifat status quo seperti ini, maka nilainilai keadilan takkan terwujud dalam pengaturan tentang BWI. Padahal eksistensi BWI dalam pengelolaan dan pengembangan wakaf sangat urgen dan harus diperhatikan secara seksama dan dipenuhi segala hal yang dapat menunjang kinerja BWI baik itu dari segi strukturnya, infrastrukturnya, maupun suprastrukturnya.

Oleh karena itu, adalah wajib hukumnya untuk mempertegas status BWI jika pemerintah menginginkan terwujudnya pengelolaan dan pengembangan wakaf yang dapat meningkatkan kesejahteraan umat. Berkenaan dengan hal ini, seyogianya status BWI ditingkatkan menjadi Lembaga Pemerintah Nonstruktural (LNS) sehingga status dan kedudukan BWI menjadi jelas dalam sistem ketatanegaraan.

Dengan begitu maka pasal yang terkait dengan hal ini yaitu pasal 47 ayat (2), yang berbunyi: "Badan Wakaf Indonesia merupakan lembaga independen dalam melaksanakan tugasnya”. Sudah tidak relevan lagi untuk diterapkan sehingga harus direkonstruksi.

Setidaknya untuk memaparkan kejelasan perubahan dan peningkatan status BWI ini, seyogyanya pasal 47 ayat (2) tersebut dapat dirumuskan dengan redaksi berikut: "Badan Wakaf Indonesia 
merupakan lembaga pemerintah nonstruktural yang bersifat mandiri dan bertanggung jawab kepada Presiden melalui Menteri". Dengan demikian, status BWI menjadi jelas sebagai lembaga pemerintah nonstruktural dan kedudukannya langsung berada di bawah Presiden.

Adapun yang dimaksudkan dengan lembaga pemerintah nonstruktural (LNS) di sini adalah LNS yang masuk dalam varian Lembaga Pemerintah non kementerian, yang berada sejajar dengan kementerian dan bukan LNS yang berada di bawah Menteri (Kementerian Agama), karena BWI dibentuk atas dasar Undang-Undang dan bukan atas dasar peraturan di bawahnya.

Selain itu, LNS yang dimaksudkan oleh penulis di sini adalah BWI sebagai LNS yang termasuk dalam jenis LNS yang sifatnya menganggarkan sendiri dan pembiayaannya dibebankan pada APBN. Oleh karena itu, dari segi budgeting, BWI akan menjadi kuat dan kesempatan untuk menjadi mandiri akan lebih terbuka luas.

Dapat dipahami bahwa dalam beberapa dekade terakhir ini, di Indonesia jumlah LNS yang dimiliki oleh Negara ataupun oleh Pemerintah semakin membludak sehingga beberapa waktu terakhir ini Pemerintah sedang menimbang kembali keberadaaan LNS-LNS dan sudah menghapus beberapa LNS yang dimiliki oleh Negara dan/atau Pemerintah. Akan tetapi, urgensi dan potensi BWI sebagai LNS sangat berpengaruh signifikan terhadap pengembangan dan pemberdayaan wakaf di Indonesia.

Selanjutnya, implikasi berubahnya status BWI menjadi lembaga nonstruktural tersebut, adalah bahwa segala pengaturan tentang BWI pun harus disesuai dengan statusnya sebagai lembaga pemerintah nonstruktural, baik itu dari stuktur, tugas pokok dan fungsi, kewenangankewenangannya, nomenklatur ataupun aturan hal lain, terkait internal dan eksternal BWI maupun birokrasi pelaksanaan wakaf.

Perubahan status BWI menjadi lembaga pemerintah nonstruktural adalah penerapan nilai keadilan dalam bentuk persamaan status BWI dengan lembaga lainnya, juga sebagai implementasi dari konsep persamaan W. Friedmann, ${ }^{12}$ yang pada pokoknya bahwa persamaan dipandang sebagai unsur keadilan, yang mengandung nilai-nilai universal dan keadilan tersebut pada satu sisi dapat diartikan sama dengan hukum, dan pada sisi lain keadilan juga merupakan tujuan hukum. Dalam mencapai tujuan tersebut,

${ }^{12}$ Lihat W. Friedmann, The Statee and The Rule of Law in Mix Economy, Steven \& Son, London, 1971, hlm. 385. 
keadilan dipandang sebagai sikap tidak memihak (impartiality). Sikap inilah yang mengandung gagasan mengenai persamaan yaitu persamaan perlakukan yang adil terhadap semua orang, dan dalam hal ini perlakuan yang adil oleh Pemerintah terhadap BWI dalam melaksanakan tugas dan fungsinya.

Dengan perubahan status ini pula ke depannya, BWI sebagai legislator perwakafan dalam membuat peraturanperaturan BWI mempunyai wewenang yang kuat. Karena dengan status lembaga yang jelas, legalitas BWI dalam pembentukan peraturan-peraturan BWI tentang perwakafan akan secara otomatis memenuhi asas kelembagaan dalam pembentukan peraturan perundangundangan.

\section{KESIMPULAN}

Badan Wakaf Indonesia (BWI) lahir berdasarkan amanat Undang-Undang Nomor 41 Tahun 2004 tentang Wakaf, dengan demikian maka BWI mempunyai kedudukan hukum yang kuat dalam struktur hukum nasional. Seiring dengan ketentuan status tersebut, tentunya Undang-Undang juga memberikan tugas, wewenang dan kewajiban bagi BWI secara kelembagaan. Namun dalam konstruksi hukum wewenang, tugas dan tanggungjawabnya terdapat beberapa kekurangan, yaitu terkait dengan status, independensi, struktur, tugas dan pembiayaan Badan Wakaf Indonesia
(BWI), yang mana hal tersebut berpengaruh sangat signifikan terhadap pelaksanaan, pengelolaan dan pengembangan perwakafan di Indonesia.

Dalam rangka merevitalisasi status, peran dan tanggung jawab Badan Wakaf Indonesia dalam pengelolaan wakaf di Indonesia diharuskan adanya kejelasan dan penguatan terhadap konstruksi hukum yang terkait wewenang, tugas, tanggungjawab, dan status kelembagaan Badan Wakaf Indonesia. Status kelembagaan Badan Wakaf Indonesia seharusnya ditingkatkan menjadi Lembaga Pemerintah Nonstruktural (LNS) sehingga menjadi jelas dalam sistem ketatanegaraan yang kedudukannya langsung berada di bawah Presiden dan dapat menganggarkan sendiri pembiayaannya yang dibebankan kepada APBN, status kelembagaan tersebut dapat disamakan dengan Badan Amil Zakat Nasional (BAZNAS) sebagai salah satu Lembaga Pemerintah Nonstruktural.

\section{DAFTAR PUSTAKA}

\section{Buku}
Ali, Muhammad Daud, Sistem Ekonomi Islam Zakat dan Wakaf, UI Press, Jakarta, 1988.

Sistem Ekonomi Zakat dan Wakaf, UI Press, Jakarta, 1998.

Direktorat Pemberdayaan Wakaf, Lahirnya UU Nomor 41 Tahun 2004 tentang Wakaf, Direktorat Jenderal Bimbingan Masyarakat Islam, Jakarta, 2006.

Direktorat Pengembangan Zakat dan Wakaf dan Direktorat Jenderal Bimbingan 
Masyarakat Islam dan Penyelenggaraan Haji, Paradigma Baru Wakaf di Indonesia, Direktorat Jenderal Bimbingan Masyarakat Islam, Jakarta, 2005.

Djunaidi, Achmad dan Thobieb Al-Asyhar, Menuju Era Wakaf Produktif, Mumtaz Publishing, Depok, 2007.

Djunaidi, Achmad dkk., Pedoman Pengelolaan dan Pengembangan Wakaf, Kementerian Agama RI, Jakarta, 2013.

Fajar, Mukti. dan Yulianto Achnmad, Dualisme Penelitian Hukum: Normatif dan Empiris, Pustaka Pelajar, Yogyakarta, 2010.

Ghazaly, Abdul Rahman. dkk., Fiqih Muamalat, Kencana, Jakarta, 2010.

Halim, Abdul, Hukum Perwakafan di Indonesia, Ciputat Press, Tangerang, 2005.

Hazairin, Demokrasi Pancasila, Bina Aksara, Jakarta, 1993.

Kholid, Hendra, Wakaf uang perspektif hukum dan ekonomi Islam. www.bwi.or.id, diakses pada 23 September 2018.

Prianto, Sigit Indra, Peran BWI Dalam Mengembangkan Wakaf Indonesia, http://sigitsoebroto.blogspot.com/20 09/06/peran-bwi-dalammengembangkan-wakaf.html, diakses pada 23 September 2018.

Shomad, Abdul, Hukum Islam Penormaan Prinsip Syari'ah dalam Hukum Islam, Kencana, Jakarta, 2010.

Soekanto, Soerjono, Pengantar Penelitian Hukum, UI Press, Jakarta, 1981.

Soekanto, Soerjono. dan Sri Mamudji, Penelitian Hukum Normatif Suatu Tinjauan Singkat, Raja Grafindo Persada, Jakarta, 2009.
Suhrawardi K. Lubis, dkk., Wakaf dan Pemberdayaan Umat, Sinar Grafika, Jakarta, 2010.

\section{Peraturan Perundang-undangan}

Undang-Undang Nomor 41 Tahun 2004 tentang Wakaf.

Peraturan Pemerintah Nomor 42 Tahun 2006 tentang Pelaksanaan UndangUndang Nomor 41 Tahun 2004 tentang Wakaf

Peraturan Badan Wakaf Indonesia Nomor 1 Tahun 2007 tentang Organisasi dan Tata Kerja Badan Wakaf Indonesia 
